\title{
Genotypic Characterization of Clinical Isolates of Staphylococcus aureus from Pakistan
}

\author{
Saeed Khan *, Bernard S. Marasa, Kidon Sung (D) and Mohamed Nawaz
}

check for updates

Citation: Khan, S.; Marasa, B.S.; Sung, K.; Nawaz, M. Genotypic Characterization of Clinical Isolates of Staphylococcus aureus from Pakistan Pathogens 2021, 10, 918. https:// doi.org/10.3390/pathogens10080918

Academic Editors: Yasser Sanad and Mohamed K. Fakhr

Received: 20 May 2021

Accepted: 18 July 2021

Published: 21 July 2021

Publisher's Note: MDPI stays neutral with regard to jurisdictional claims in published maps and institutional affiliations.

Copyright: (c) 2021 by the authors. Licensee MDPI, Basel, Switzerland. This article is an open access article distributed under the terms and conditions of the Creative Commons Attribution (CC BY) license (https:// creativecommons.org/licenses/by/ $4.0 /)$.
Division of Microbiology, National Center for Toxicological Research, US Food and Drug Administration, Jefferson, AR 72079, USA; bernard.marasa@fda.hhs.gov (B.S.M.); kidon.sung@fda.hhs.gov (K.S.); Mohamed.nawaz@fda.hhs.gov (M.N.)

* Correspondence: Saeed.Khan@fda.hhs.gov; Tel.: +1-(870)-543-7197; Fax: +1-(870)-543-7307

\begin{abstract}
In this study, we compared pulsed-field gel electrophoretic (PFGE), multilocus sequence typing (MLST), Staphylococcal cassette chromosome mec (SCCmec), spa typing, and virulence gene profiles of 19 Panton-Valentine leucocidin (PVL)-positive, multidrug-, and methicillin-resistant clinical Staphylococcus aureus (MRSA) isolates obtained from a hospital intensive care unit in Pakistan. The isolates exhibited 10 pulsotypes, contained eight adhesin genes (bbp, clfA, clfB, cna, fnbA, fnbB, map-eap, and spa), 10 toxin genes (hla, hlb, hld, hlg, pvl, sed, see, seg, seh, and tst), and two other virulence genes $(c f b, v 8)$ that were commonly present in all isolates. The spa-typing indicated seven known spa types ( $\mathrm{t} 030, \mathrm{t} 064, \mathrm{t} 138, \mathrm{t} 314, \mathrm{t} 987, \mathrm{t} 1509$, and $\mathrm{t} 5414)$ and three novel spa types. MLST analysis indicated eight ST types (ST8, ST15, ST30, ST239, ST291, ST503, ST772, and ST1413). All isolates belonged to the agr group 1. Most of the isolates possessed SCCmec type III, but some isolates had it in combination with types SCCmec IV and V. The presence of multidrug-resistant MRSA isolates in Pakistan indicates poor hygienic conditions, overuse of antibiotics, and a lack of rational antibiotic therapy that have led to the evolution and development of hypervirulent MRSA clones. The study warrants development of a robust epidemiological screening program and adoption of effective measures to stop their spread in hospitals and the community.
\end{abstract}

Keywords: methicillin resistance; virulence; genes; MLST; SCCmec; Staphylococcus aureus; evolution

\section{Introduction}

MRSA is the major source of hospital-acquired infections and is of particular concern due to its involvement in high incidences of morbidity and mortality worldwide [1-3]. Resistance to methicillin is conferred by a mecA gene that was first discovered in 1961 among nosocomial $S$. aureus isolates, and since then, it has been independently transferred multiple times into the $S$. aureus chromosome rather than originating from a single ancestral strain [4]. While the incidence of MRSA infections and their epidemiology is well documented in western countries, data from the National Nosocomial Infections Surveillance System of Pakistan suggests that incidences of MRSA infections have increased from $35.9 \%$ to $66.7 \%$ in Pakistan during 2009-2019 [5-7]. The presence of other virulence factors, extracellular enterotoxin genes, and Panton-Valentine leucocidin cytotoxin (PVL) genes makes MRSA highly pathogenic and difficult to treat [8]. This organism causes a variety of infections, such as boils, furuncles, styes, impetigo, and other superficial infections, in humans [9,10]. It is also known to cause serious infections, such as pneumonia, deep abscesses, osteomyelitis, endocarditis, phlebitis, mastitis, and meningitis, in immunocompromised and severely ill individuals [11,12]. Among life-threatening diseases, MRSA has been implicated in unusually invasive pathogenic diseases, such as severe septicemia, necrotizing fasciitis, and pneumonia. Hospital-acquired MRSA (HA-MRSA) strains also exhibit resistance to multiple antibiotics, including macrolides and fluoroquinolones, which poses serious challenges to the treatment of infections $[13,14]$. MRSA is no longer limited to hospital settings; community-acquired MRSA (CA-MRSA) is also becoming a major threat to public 
health and can be transmitted in homes, workplaces, and child-care facilities [15]. The association of Panton-Valentine leucocidin (PVL) genes in CA-MRSA causes infections in healthy young and immunocompetent hosts, sometimes with fatal outcomes [16]. PVL genes cause leukocyte destruction and necrotizing pneumonia that can kill patients within three days. Community-acquired pneumonia (CAP) afflicts young and healthy individuals and leads to more than $40 \%$ mortality [17]. PVL-positive MRSA has played a critical role in several outbreaks and causes life-threatening bacterial infections. PVL-positive CA-MRSA strains usually cause soft-tissue infections, but PVL has also been viewed as a key virulence factor that helps bacteria in targeting and killing neutrophils. In one of the studies, however, this view was challenged, wherein the removal of PVL from CA-MRSA strains did not result in a loss of infectivity or neutrophils destruction [18]. It has been shown that the worldwide spread of PVL-positive CA-MRSA was not due to a single clone, but rather, it emerged multiple times on different continents [19]. PVL has been suspected in increasing the expression of staphylococcal protein $\mathrm{A}$, which is an important pro-inflammatory factor for pneumonia. The presence of PVL has also been shown to increase virulence in some strains of $S$. aureus. Most CA-MRSA isolates studied have been shown to harbor PVL genes [20].

The genome of $S$. aureus contains large areas of differences, even within species, and some of them carry virulence factors, toxins, and the genes for antimicrobial resistance [21]. It is believed that the $S$. aureus genome contains $\sim 22 \%$ of dispensable genetic material, as well as several dispensable regions of its genome, and these genetic variations are likely responsible for a poorly understood phenomenon of disease and host specificity. Several techniques, such as molecular typing of $S$. aureus using amplified fragment length polymorphism [22], pulsed field gel electrophoretic analysis (PFGE) [23], and the presence of virulence genes and factors [24], have been used successfully to determine clonal relationships and for source tracking in epidemiological screening of these isolates. In this study, we used some of these techniques to explore the diversity and distribution of prevalent clonal isolates, including the presence of virulence factors and toxin genes, PFGE, ST, spa typing, and SCCmec patterns, in six PVL-positive CA-MRSA and thirteen PVL-positive HA-MRSA isolates from Pakistan. The data yielded novel information that could be helpful in understanding the evolution and emergence of PVL-positive CA-MRSA isolates, risk assessment of the threats posed by these isolates, and designing strategies to manage and control S. aureus infections.

\section{Results}

\subsection{Antimicrobial Susceptibility and Resistance Genes}

Disk diffusion assays indicated that all isolates were resistant to multiple antibiotics, including ampicillin, chloramphenicol (except for isolate 50), erythromycin (except for isolate 15), gentamicin, kanamycin, oxacillin, methicillin, penicillin, and tetracycline, and all were susceptible to vancomycin. The antibiograms and MIC data are presented in Table S1. PCR amplification of the resistance genes that confer resistance to chloramphenicol, erythromycin, tetracycline, trimethoprim, methicillin, and $\beta$-lactams indicated the presence of multiple genes that conferred resistance to these antibiotics. Most of the isolates resistant to chloramphenicol exhibited the presence of chloramphenicol resistance genes, cat( $p$ C194), cat( $p C 221)$, and cat( $p C 223)$, except for isolate 10, which lacked cat( $p$ C194), and isolate 50, which was susceptible to chloramphenicol and did not possess any of the genes mentioned above (Table 1, Figure 1C). A majority of the isolates resistant to erythromycin contained the ermB gene alone or in combination with the sat4 gene. Isolate 15, which was susceptible to erythromycin, did not contain any of these genes. Among the tetracycline resistance genes tested, most isolates showed tet $M$, tet $S$, and tet $W$ genes, except for isolates 50 and 52 that lacked the $t e t M$ gene. Isolates 32 and 33 contained an additional tetK gene, and isolates 10, 25, and 32 contained the tet $L$ gene. All isolates contained the trimethoprim resistance gene $d f r A$ and the methicillin resistance gene mecA. Of the 19 isolates, all but five isolates (isolates 10, 15, 25, 30, and 37) contained the blaZ gene. 
Table 1. Distribution of antimicrobial resistance genes in MRSA isolates.

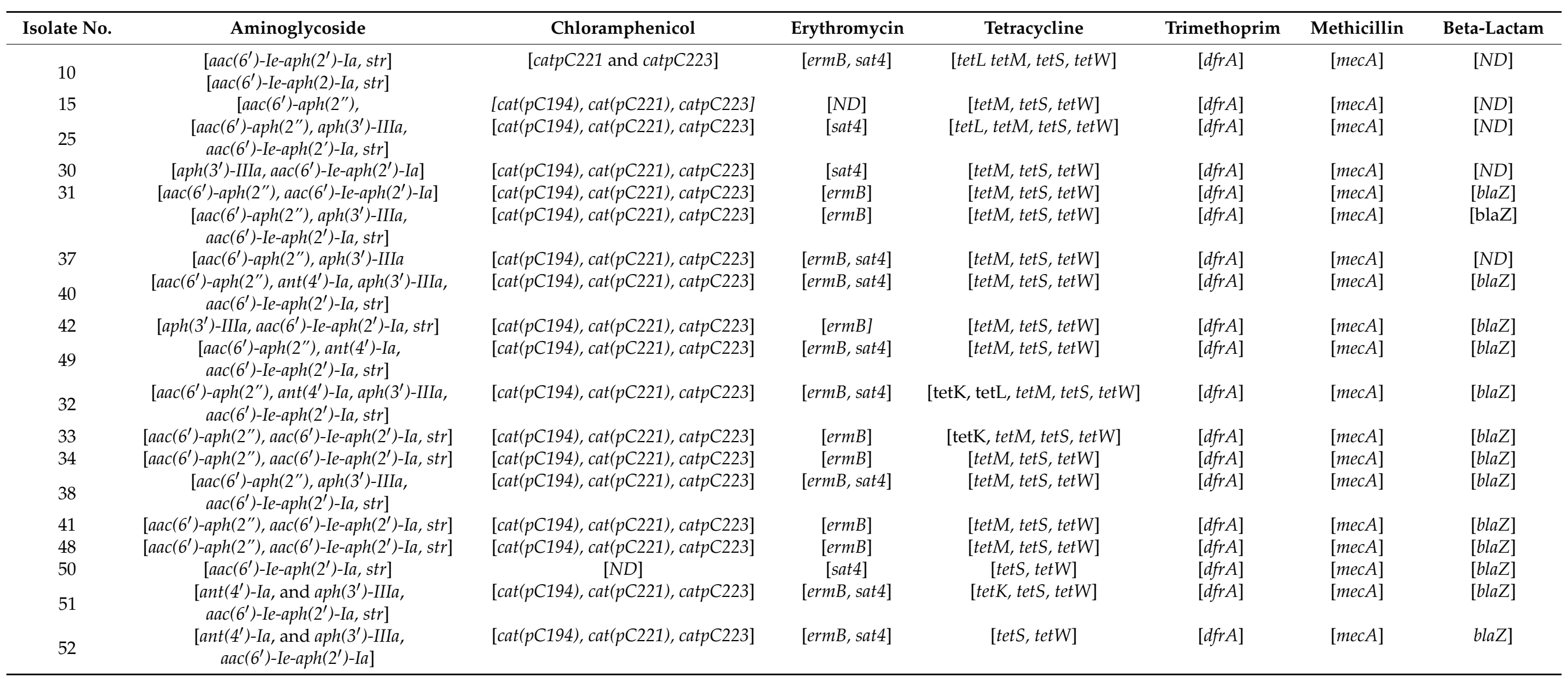




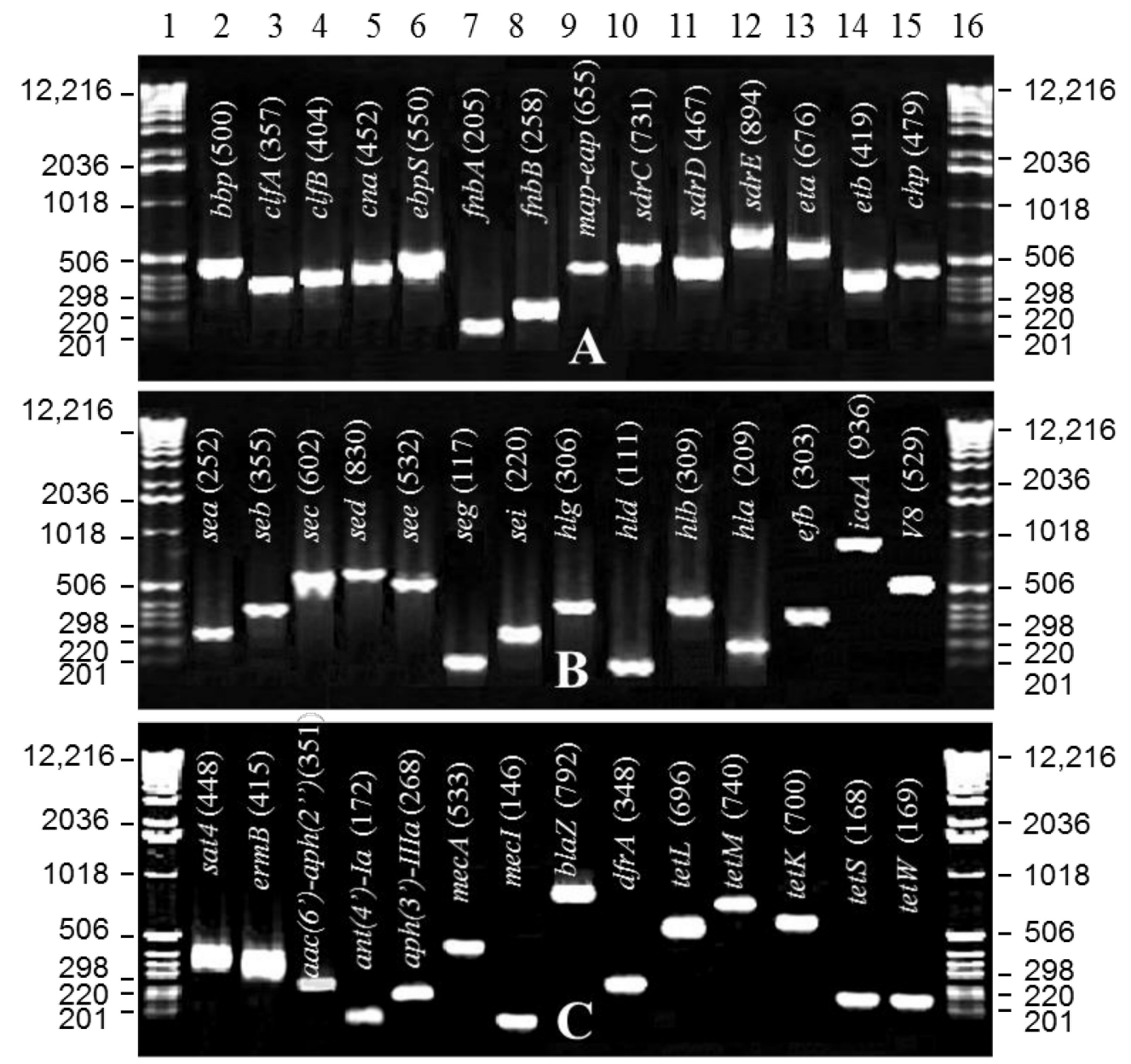

Figure 1. Virulence and antimicrobial resistance gene profile of MRSA isolates. PCR amplicons of various gene products were separated on $2 \%$ agarose gels. Lanes 1 and 16, 100-bp DNA ladder; Lanes 2 to 9 and 13, 14, 15 in gel $\mathbf{A}$ and lanes 2 to 15 in gel $\mathbf{B}$ indicate the amplicons of different virulence genes from a representative isolate 32. Lanes 10 to 12 in gel A represent virulence genes from isolate 50. In gel C, lanes 2 to 15 show the amplicons of various antimicrobial resistance genes from a representative isolate 32. PCR amplicon sizes are shown in parentheses.

\subsection{PFGE Analysis}

Separation of the SmaI-digested chromosomal DNA fragments from the isolates by PFGE indicated 10 different patterns. Nineteen MRSA isolates were grouped into 10 pulsedfield gel electrophoretic (PFGE) groups. PFGE profile 1 (Figure 2, Table 2) was comprised of six MRSA isolates of perirectal origin (isolates 32, 33, 34, 38, 41, 48). PFGE profile 2 consisted of five isolates of nasal origin (isolates 15, 25, 31, 37, 40). PFGE profiles 3 to 10 were represented by single isolates 10, 30, 35, 42, 49 and 50, 51, and 52, respectively (Figure 2, Table 2). 


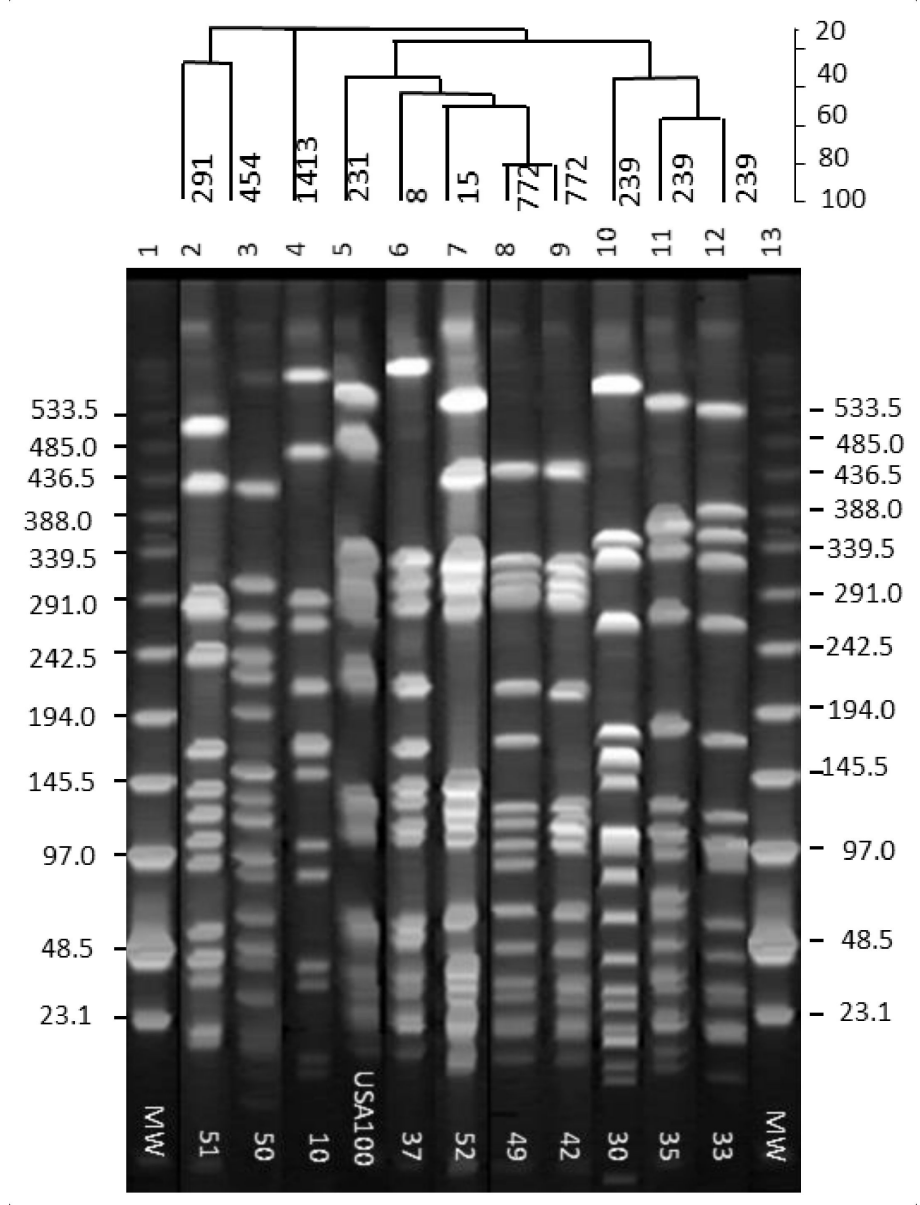

Figure 2. Pulsed-field gel electrophoretic profiles of MRSA isolates in 1\% Seakem gold agarose gel. Lane numbers are at the top of the gel, and isolate numbers are shown in the inset. Molecular weight marker sizes are shown on either side of the gel. The \% similarity among the isolates is indicated by a dendrogram on top of the gel above the lane numbers.

\subsection{PVL Gene Amplification and MLST and spa-Typing}

Sequencing of $\sim 450$-bp internal fragments of seven housekeeping genes followed by mapping via the https://pubmlst.org/organisms/staphylococcus-aureus/ (accessed on 20 April 2021) indicated eight different MLST patterns (Table 2). The most common pattern exhibited by 9 of 19 isolates was ST239 with the allelic profile 2-3-1-1-4-4-3. Three isolates presented the ST8 profile (3-3-1-1-4-4-3), two isolates showed ST772 (1-1-1-1-22-111 ), and one of each of the five other isolates had ST30 (2-2-2-2-6-3-2), ST503 (2-2-22-13-3-2), ST291 (3-37-19-2-20-26-32), ST15 (13-13-1-1-12-11-13), and ST1413 (6-5-6-2-162-14-5) profiles. Sequence analysis of the $X$ region of the spa gene indicated eight different spa-types, the most common being the spa-type t030 represented by seven isolates $(31,32,33,34,35$, 41, and 48) (Table 2). The spa-type t064 was present in isolates 25 and 37; these isolates were also found to have two nucleotide substitutions in the $3^{\prime}$ flanking region (Table 3). Sequence analysis revealed spa-types t138 in isolates 40 and 50 and t5414 in isolates 42 and 49. Spa-types $\mathrm{t} 314, \mathrm{t} 987, \mathrm{t} 1149$, and $\mathrm{t} 1509$ were present in isolates 10, 30, 51, and 52, respectively. Three new spa-types were identified in isolate numbers 15, 38, and 51. Each new spa-type differed from each other based on flanking and variable $X$ region sequences (Table 3). Isolate 15 presented two new 24-bp VNTRs and different $5^{\prime}$ and $3^{\prime}$ flanking sequences, and isolate 38 showed a new 24-bp VNTR immediately before the $3^{\prime}$ flanking sequence. Although isolate 51 exhibited a known spa type, it contained a novel $5^{\prime}$ flanking sequence. The results of PCR assays for different leukocidin genes are shown in Table 4. 
Table 2. MLST, spa, SCCmec, agr, and capsular typing of MRSA isolates.

\begin{tabular}{|c|c|c|c|c|c|c|c|c|c|}
\hline $\begin{array}{l}\text { PFGE } \\
\text { Profile }\end{array}$ & $\begin{array}{c}\text { Isolate } \\
\text { No }\end{array}$ & Origin & $\begin{array}{l}\text { Infection } \\
\text { Type }\end{array}$ & $\begin{array}{l}\text { Symptoms/Reasons } \\
\text { Admitted for }\end{array}$ & $\begin{array}{l}\text { MLST } \\
\text { Type }\end{array}$ & $\begin{array}{l}\text { spa } \\
\text { Type }\end{array}$ & $\begin{array}{l}\text { SCCmec } \\
\text { Type }\end{array}$ & $\begin{array}{c}a g r \\
\text { Group }\end{array}$ & $\begin{array}{l}\text { Capsular } \\
\text { Genotype }\end{array}$ \\
\hline 1 & 32 & $\mathrm{P}$ & HA & DNR Colitis Tracheostomy & ST239 & t030 & III & I & 8 \\
\hline 1 & $33 *$ & $\mathrm{P}$ & $\mathrm{CA}$ & Septic Shock & ST239 & $\mathrm{t} 030$ & III & $\mathrm{I}$ & 8 \\
\hline 1 & 34 & $\mathrm{P}$ & CA & Intestinal Obstruction & ST239 & $\mathrm{t} 030$ & III & I & NT \\
\hline 1 & 41 & $\mathrm{P}$ & HA & Anxiolytic Poisoning & ST239 & t030 & III & $\mathrm{I}$ & 8 \\
\hline 1 & 48 & $\mathrm{P}$ & $\mathrm{CA}$ & SOB, Fever & ST239 & t030 & III & I & 8 \\
\hline 1 & 38 & $\mathrm{P}$ & HA & CuSo4 Poisoning & ST8 & New & $\mathrm{V}$ & I & 5 \\
\hline 2 & 15 & $\mathrm{~N}$ & HA & Hepato-Splenomegaly & ST239 & New & III & $\mathrm{I}$ & 8 \\
\hline 2 & $25 *$ & $\mathrm{~N}$ & CA & Chronic Renal Failure & ST8 & t064 & IVa & I & 5 \\
\hline 2 & $31 *$ & $\mathrm{~N}$ & $\mathrm{HA}$ & Tetanus, Locked Jaw & ST239 & $\mathrm{t} 030$ & III, IVa & $\mathrm{I}$ & 8 \\
\hline 2 & 37 & $\mathrm{~N}$ & HA & Cardiogenic shock & ST8 & t064 & IVa & I & 5 \\
\hline 2 & $40^{*}$ & $\mathrm{~N}$ & HA & Kyphoscoliosis & ST30 & $\mathrm{t} 138$ & IVa & I & 8 \\
\hline 3 & $10 *$ & $\mathrm{~N}$ & HA & Guillain Barr Syndrome & ST1413 & $\mathrm{t} 314$ & III, V & I & 8 \\
\hline 4 & 30 & $\mathrm{~N}$ & HA & Acute unconsciousness & ST239 & t987 & III & $\mathrm{I}$ & 8 \\
\hline 5 & 35 & $\mathrm{~N}$ & HA & Dilated Cardiomyopathy & ST239 & t030 & III & $\mathrm{I}$ & 8 \\
\hline 6 & 42 & $\mathrm{~N}$ & CA & Hepato-Splenomegaly & ST772 & $\mathrm{t} 5414$ & III & $\mathrm{I}$ & 5 \\
\hline 7 & 49 & $\mathrm{~N}$ & $\mathrm{CA}$ & Intestinal Obstruction & ST772 & $\mathrm{t} 5414$ & III & $\mathrm{I}$ & 5 \\
\hline 8 & 50 & $\mathrm{P}$ & HA & CuSo4 Poisoning & ST503 & $\mathrm{t} 138$ & III, IVa, V & I & 5 \\
\hline 9 & $51 *$ & $\mathrm{~N}$ & $\mathrm{HA}$ & Chronic Renal Failure & ST291 & $\mathrm{t} 1149$ & III, V & $\mathrm{I}$ & NT \\
\hline 10 & 52 & $\mathrm{P}$ & HA & Neuropathy, Tuberculosis & ST15 & t1509 & III, IVa, V & I & 5 \\
\hline
\end{tabular}

$\mathrm{P}=$ Perirectal; $\mathrm{N}=$ Nasal; CA = Community-acquired; HA = Hospital-acquired; NT = Non-typable; * Patient died.

Table 3. Differences in the spa-types of various MRSA isolates.

\begin{tabular}{|c|c|c|c|}
\hline \multicolumn{2}{|c|}{ X-Region of the Staphylococcal Protein A Gene } & spa Type & Isolate \# \\
\hline \multicolumn{2}{|c|}{ 5' FL-W1 G1 K1 A1 Q1 K1 A1 O1 M1 Q1-3 FL' } & t987 & 30 \\
\hline \multicolumn{2}{|c|}{ 5' FL-Y1 H1 G1 C1 M1 B1 Q1 B1 L1 O1 AAGAAGATGGTAACGGAGTACATG-3’ FL } & t064 & 25,37 \\
\hline \multicolumn{2}{|c|}{ 5' FL-T1 K1 J1 E1 F1 M1 B1 P1 B1-3' FL } & $\mathrm{t} 5414$ & 42,49 \\
\hline \multicolumn{2}{|c|}{ 5' FL-W1 G1 K1 A1 Q1 Q1-3' FL } & t030 & $31-35,41,48$ \\
\hline \multicolumn{2}{|c|}{ 5' FL-X1 K1 A1 O1 M1 Q1-3' FL } & $\mathrm{t} 138$ & 40,50 \\
\hline \multicolumn{2}{|c|}{ 5' FL-X1 M1 J1 H2 M1-3' FL } & t314 & 10 \\
\hline \multicolumn{2}{|c|}{$5^{\prime}$ FL-U1 J1 G1 J1-3' FL } & t1509 & 52 \\
\hline \multicolumn{2}{|c|}{ 5' FL-Y1 H1 G1 C1 M1 B1 Q1 B1 L1 AAATAAGATGGTAACTGATTACATG-3’ FL } & New & 38 \\
\hline \multicolumn{2}{|c|}{$\begin{array}{c}5^{\prime}-\text { CCCAAGACAGCAACAAGCCTGGTA AGAGAGGACGGCAACAAACCTGGT- } \\
\text { AAAGAAGACAGCAAAAAAACTGGCAAGACGATGGCAACAAGCCGGGCA--3' FL }\end{array}$} & New & 15 \\
\hline \multicolumn{2}{|c|}{$\begin{array}{l}\text { 5' - TGNAAGACGGCAACAAACCTGGTA AAAGAAGACAACGAAAAACCTGGT } \\
\text { AAAGAAGATGGCAACTAGCCTGGT B1 B1 AAAGAAGACGGCTACAAGCCTGGT--3' FL }\end{array}$} & New & 51 \\
\hline A1: AAAGAAGACAACAAAAAACCTGGC & B1: AAAGAAGACAACAAAAAACCTGGT & \multicolumn{2}{|c|}{ C1: AAAGAAGACAACAAAAAGCCTGGC } \\
\hline E1: AAAGAAGACGGCAACAAACCTGGC & F1: AAAGAAGACAACAACAAGCCTGGC & \multicolumn{2}{|c|}{ G1: AAAGAAGACAACAACAAGCCTGGT } \\
\hline H1: AAAGAAGACAATAACAAGCCTGGC & H2: AAAGAAGATGGCAACAAGCCTAGT & \multicolumn{2}{|c|}{ J1: AAAGAAGACGGCAACAAACCTGGT } \\
\hline K1: AAAGAAGACGGCAACAAACCTGGT & L1: AAAGAAGACGGCAACAAGCCTGGC & \multicolumn{2}{|c|}{ M1: AAAGAAGACGGCAACAAGCCTGGT } \\
\hline 01: AAAGAAGATGGCAACAAACCTGGT & P1: AAAGAAGATGGCAACAAGCCTGGC & \multicolumn{2}{|c|}{ Q1: AAAGAAGATGGCAACAAGCCTGGT } \\
\hline T1: GAGGAAGACAACAAAAAACCTGGT & X1: GAGGAAGACAACAACAAGCCTGGT & Y1: GAGGAAC & ACAAGCCTGGC \\
\hline W1: GAGGAAGACAACAACAAGCCTGGC & 5'-FL: TAAACGATGCTCAAGCACCAAAAG & \multicolumn{2}{|c|}{$\begin{array}{l}\text { Y1: GAGGAAGACAATAACAAGCCTGGC } \\
\text { 3'-FL: AAGAAGACGGCAACGGAGTACATG }\end{array}$} \\
\hline
\end{tabular}

Bold and numbered letters indicate a single letter code for polymorphic 24-bp VNTR sequences within the $3^{\prime}$ coding region $X$ of the spa gene.New VNTRs are shown with their full length 24-bp sequences indicated by a bolded starting letter. The $5^{\prime}$ and $3^{\prime}$ flanking regions containing variations from the indicated sequences are italicized and underlined. 
Table 4. Distribution of Staphylococcal enterotoxin, adhesion, hemolysin, and other virulence genes in human clinical MRSA isolates.

\begin{tabular}{|c|c|c|c|c|}
\hline $\begin{array}{l}\text { Isolate } \\
\text { No. }\end{array}$ & Toxin Genes & Adhesin Genes & $\begin{array}{l}\text { Other Virulence } \\
\text { Genes }\end{array}$ & $\begin{array}{l}\text { Hemolysin } \\
\text { Activity }\end{array}$ \\
\hline 10 & $\begin{array}{c}\text { [eta, sea, seb, sec, sei, sej, hla, hlb, hld, hlg, pvl } \\
\text { (lukS, lukF, lukM, lukE-D), sed, see, seg, seh, tst }]\end{array}$ & $(e b p S, b b p, c a n, c l f A, c l f B, f n b A, f n b B$, map-eap, spa) & $(i c a, c f b, v 8)$ & $\gamma$ \\
\hline 15 & $\begin{array}{c}{[\mathrm{seb}, \mathrm{sec}, \mathrm{hla}, \mathrm{hlb}, \mathrm{hld}, \mathrm{hlg}, \mathrm{pvl}(\mathrm{lukE-D}), \mathrm{sed}, \mathrm{see},} \\
\text { seg, seh, tst }]\end{array}$ & $(e b p S, b b p, c a n, c l f A, c l f B, f n b A, f n b B$, map-eap, spa) & $(c f b, v 8)$ & $\alpha$ \\
\hline 25 & $\begin{array}{c}{[s e a, \text { seb, sec, hla, hlb, hld, hlg, pvl (lukE-D), sed, }} \\
\text { see, seg, seh, tst }\end{array}$ & $(b b p, c a n, c l f A, c l f B, f n b A, f n b B$, map-eap, spa) & $(i c a, c f b, v 8)$ & $\alpha$ \\
\hline 30 & $\begin{array}{c}{[e t a, \text { sea, seb, sec, sei, sej, hla, hlb, hld, hlg, pvl }} \\
(\text { lukS, lukF, lukM, lukE-D), sed, see, seg, seh, tst] }\end{array}$ & $(b b p, c a n, c l f A, c l f B, f n b A, f n b B$, map-eap, spa) & $(\operatorname{chp}, i c a, c f b, v 8)$ & $\gamma$ \\
\hline 31 & $\begin{array}{c}{[e t a, s e b, s e c, \text { sei, hla, hlb, hld, hlg, pvl (lukE-D), }} \\
\text { sed, see, seg, seh, tst }]\end{array}$ & $(e b p S, b b p, c a n, c l f A, c l f B, f n b A, f n b B$, map-eap, spa $)$ & $(i c a, c f b, v 8)$ & $\gamma$ \\
\hline 35 & $\begin{array}{l}\text { [eta, seb, sec, sei, sej, hla, hlb, hld, hlg, pvl (lukS, } \\
\text { lukF, lukM, lukE-D), sed, see, seg, seh, tst] }\end{array}$ & $(b b p, c a n, c l f A, c l f B, f n b A, f n b B$, map-eap, spa) & $(\operatorname{chp}, i c a, c f b, v 8)$ & $\gamma$ \\
\hline 37 & $\begin{array}{c}\text { [eta, sea, seb, sec, sej, hla, hlb, hld, hlg, pvl } \\
\text { (lukE-D), sed, see, seg, seh, tst] }\end{array}$ & $(b b p, c a n, c l f A, c l f B, f n b A, f n b B$, map-eap, spa) & $(c h p, i c a, c f b, v 8)$ & $\alpha$ \\
\hline 40 & $\begin{array}{l}\text { [eta, sea, seb, sec, sej, hla, hlb, hld, hlg, pvl (lukS, } \\
\text { lukF, lukM, lukE-D), sed, see, seg, seh, tst] }\end{array}$ & $(b b p, c a n, c l f A, c l f B, f n b A, f n b B$, map-eap, spa $)$ & $(\operatorname{chp}, i c a, c f b, v 8)$ & $\beta$ \\
\hline 42 & $\begin{array}{c}{[e t a, \text { seb, sec, sei, hla, hlb, hld, hlg, pol (lukS, lukF, }} \\
\text { lukM, lukE-D), sed, see, seg, seh, tst] }\end{array}$ & $(e b p S, b b p, c a n, c l f A, c l f B, f n b A, f n b B$, map-eap, spa $)$ & $(c h p, i c a, c f b, v 8)$ & $\alpha$ \\
\hline 49 & $\begin{array}{c}{[e t a, \text { sea, seb, sec, sei, sej, hla, hlb, hld, hlg, pvl }} \\
(\text { lukS, lukF, lukM, lukE-D), sed, see, seg, seh, tst] }\end{array}$ & $(b b p, c a n, c l f A, c l f B, f n b A, f n b B$, map-eap, spa) & $(\operatorname{chp}, i c a, c f b, v 8)$ & $\beta$ \\
\hline 32 & $\begin{array}{l}\text { [eta, sea, seb, sec, sei, hla, hlb, hld, hlg, pvl (lukS, } \\
\text { lukF, lukM, lukE-D), sed, see, seg, seh, tst] }\end{array}$ & $(e b p S, b b p, c a n, c l f A, c l f B, f n b A, f n b B$, map-eap, spa $)$ & $(c h p, i c a, c f b, v 8)$ & $\gamma$ \\
\hline 33 & $\begin{array}{l}\text { [eta, sei, sej, hla, hlb, hld, hlg, pvl (lukS, lukF, } \\
\text { lukM, lukE-D), sed, see, seg, seh, tst] }\end{array}$ & $(e b p S, b b p, c a n, c l f A, c l f B, f n b A, f n b B$, map-eap, spa $)$ & $(c h p, i c a, c f b, v 8)$ & $\gamma$ \\
\hline 34 & $\begin{array}{l}\text { [eta, sec, sei, hla, hlb, hld, hlg, pvl (lukS, lukF, } \\
\text { lukM, lukE-D), sed, see, seg, seh, tst] }\end{array}$ & $(e b p S, b b p, c a n, c l f A, c l f B, f n b A, f n b B$, map-eap, spa) & $(c h p, i c a, c f b, v 8)$ & $\gamma$ \\
\hline 38 & $\begin{array}{l}\text { [eta, sea, seb, sec, sei, hla, hlb, hld, hlg, pvl (lukS, } \\
\text { lukF, lukM, lukE-D), sed, see, seg, seh, tst] }\end{array}$ & $(b b p, c a n, c l f A, c l f B, f n b A, f n b B$, map-eap, spa) & $(c h p, i c a, c f b, v 8)$ & $\beta$ \\
\hline 41 & $\begin{array}{c}\text { [eta, seb, sec, sei, sej, hla, hlb, hld, hlg, pvl (lukS, } \\
\text { lukF, lukM, lukE-D), sed, see, seg, seh, tst] }\end{array}$ & $(e b p S, b b p, c a n, c l f A, c l f B, f n b A, f n b B$, map-eap, spa $)$ & $(c h p, i c a, c f b, v 8)$ & $\alpha$ \\
\hline 48 & $\begin{array}{l}\text { [eta, seb, sec, sei, sej, hla, hlb, hld, hlg, pvl (lukS, } \\
\text { lukF, lukM, lukE-D), sed, see, seg, seh, tst] }\end{array}$ & $(e b p S, b b p, c a n, c l f A, c l f B, f n b A, f n b B$, map-eap, spa $)$ & $(\operatorname{chp}, i c a, c f b, v 8)$ & $\alpha$ \\
\hline 50 & $\begin{array}{l}\text { [sea, seb, sec, sei, sej, hla, hlb, hld, hlg, pvl (lukS, } \\
\text { lukF, lukM, lukE-D), sed, see, seg, seh, tst] }\end{array}$ & $(b b p, c a n, c l f A, c l f B, f n b A, f n b B$, map-eap, spa) & $(c h p, i c a, c f b, v 8)$ & $\beta$ \\
\hline 51 & $\begin{array}{c}{[e t a, \text { sea, seb, sec, hla, hlb, hld, hlg, pvl (lukS, lukF, }} \\
\text { lukM, lukE-D), sed, see, seg, seh, tst] }\end{array}$ & $(e b p S, b b p, c a n, c l f A, c l f B, f n b A, f n b B$, map-eap, spa) & $(c h p, i c a, c f b, v 8)$ & $\beta$ \\
\hline 52 & $\begin{array}{c}\text { [eta, sea, seb, sec, hla, hlb, hld, hlg, pvl (lukS, lukF, } \\
\text { lukM, lukE-D), sed, see, seg, seh, tst] }\end{array}$ & $(e b p S, b b p, c a n, c l f A, c l f B, f n b A, f n b B$, map-eap, spa) & $(c h p, i c a, c f b, v 8)$ & $\alpha$ \\
\hline
\end{tabular}

All the genes that are in bold and italic were common among all the isolates.

\subsection{SCCmec and agr Group Typing}

Of the 19 MRSA isolates tested for SCCmec types, 10 isolates showed SCCmec type III (isolates 15, 30, 32, 33, 34, 35, 41, 42, 48, 49), one showed SCCmec III + IVa (isolate 31), two presented SCCmec III + V (isolates 10,51), two exhibited SCCmec III + IVa + V (isolates 50, 52), three showed SCCmec IVa (isolates 25, 37, 40), and one presented SCCmec V (isolate 38). All detected SCCmec types belonged to agr group I (Table 2).

\subsection{Capsular Polysaccharides}

Of the 19 MRSA isolates tested, seven isolates $(25,37,38,42,49,50,52)$ showed cap 5 , and 10 isolates $(10,15,30,31,32,33,35,40,41,48)$ exhibited cap 8 . Two of the isolates (isolates 34 and 51) were non-typable (Table 2).

\subsection{Toxin, Adhesin, Virulence and Hemolysin Genes}

Of the 12 adhesin genes ( $f n b A, f n b B, c l f A, c l f B, c n a, s p a, s d r C, s d r D, s d r E, b b p, e b p S$, and map-eap) tested, eight genes ( $b b p, c n a, c l f A, c l f B, f n b A, f n b B$, map-eap, and spa) were common to all isolates (Figure 1A,B, Table 4). PCR assays of the 19 toxin genes (edin, eta, etb, hla, hlb, $h l d, h l g, h l g 2, p v l$, sea, seb, sec, sed, see, seg, seh, sei, sej, tst) indicated the presence of 10 genes 
( $h l a, h l b, h l d, h l g, p v l$, sed, see, seg, seh, tst) that were common to all isolates (Figure 1A,B, Table 4). The two PVL genes, $l u k S-P V$ and $l u k F-P V$, yielded PCR products at 538 and $460 \mathrm{bp}$, respectively. They were present in most of the isolates tested but absent from isolates 15, 25, 31, and 37 (Table 4). The lukM gene, which acts like $l u k F-P V$ in combination with $l u k S$ or a hemolysin gene $h l g 2$, was also absent from these isolates. Five other virulence genes $(\operatorname{arc} A$, $c f b, c h p, i c a, v 8)$ were tested, and only two $(c f b, v 8)$ were common to all isolates. Based on the hemolysin assays on sheep blood agar plates and PCR analysis, the isolates were found to possess $\alpha, \beta$, or $\gamma$ hemolysin genes. The hemolysin gene $\alpha$ was present in isolates 15,25 , $37,42,48$, and 52 (Table 4). Those that contained hemolysin gene $\beta$ were isolates 38, 40, 49, 50, and 51. Isolates 10, 30, 31, 32, 33, and 34 exhibited the $\gamma$ hemolysin gene (Table 4).

\section{Discussion}

MRSA isolates pose a serious threat to public health and are a global cause of concern regarding health care- and community-associated infections $[25,26]$. Studies of invasive MRSA isolates have recognized multiple clones of MRSA that are circulating worldwide, where strains of clonal complex (CC) 5 and CC8 are the most ubiquitous and most diverse $[27,28]$. Population-based studies of invasive MRSA infections in the United States indicate that MRSA clones of ST5 (CC5) and ST8 (CC8) are the predominant causative strains in health care-associated bacteremia [29]. There are relatively few studies of the distribution of MRSA and their prevalence among Pakistani isolates, which make it difficult to compare MRSA strain types in Pakistan to those in other countries, such as the most recent European MRSA surveillance data and the US data [30,31]. Only a few studies from Pakistan characterized MRSA isolates for the presence of PVL genes and SCCmec, PFGE, and ST typing [30-32]; none of these studies explored the presence of virulence, adhesion, and enterotoxin genes among MRSA isolates from this geographical region. We used PFGE, MLST, spa, and SCCmec typing techniques to understand the genotypic diversity and relationship, evolutionary changes, distribution pattern of VNTRs within the spa region, SCCmec, agr grouping, and distribution of various virulence, toxin, and antimicrobial resistance genes among 19 CA- and HA-MRSA isolates from Pakistan. The data provided a wealth of new information, and the 19 isolates exhibited 10 different PFGE profiles and eight different ST patterns. All isolates with identical PFGE profiles did not exhibit the same ST profile, and likewise, isolates with different PFGE profiles shared similar ST profiles. For example, isolate 38 from the PFGE group I, which contained six isolates, exhibited the ST8 profile, while others in the group exhibited the ST239 pattern. Moreover, five MRSA isolates representing PFGE profile 2 showed three different ST profiles (ST239, ST8, and ST30). ST239 and ST8 profiles in this group matched those seen in PFGE group I. It has been reported that ST239 types evolved as a single locus variant of ST8 and ST30 [33,34]. Here, it appears that the ST239 observed in isolates with PFGE profiles 1,2, 4, and 5 evolved either from ST8 or ST30 clones that once were predominantly present in the MRSA isolates from Pakistan, according to region-specific information from the MLST database (https: / / pubmlst.org/organisms / staphylococcus-aureus/, accessed on 20 April 2021). Our study results agree with earlier reports of the prevalence of ST239 and ST8 clones among MRSA isolates from Pakistan [31,32]. MRSA isolates exhibiting independent PFGE profiles 3, 6, 7, 8, 9, and 10 represented by isolates 10, 42, 49, 50, 51, and 52, respectively, appear to have evolved independently. These isolates presented five known ST types (ST1413, ST772, ST503, ST291, and ST15). Among these isolates, CA-MRSA isolates 42 and 49 showed a common ST772 profile and approximately $80 \%$ similarity based on their PFGE profiles. Isolate 42 seemed to have either evolved from isolate 49 due to deletion or isolate 49 evolved from isolate 42 due to acquisition of extra genetic elements.

CA- and HA-MRSA isolates are often differentiated by the type of SCCmec elements and drug-resistant phenotypes present on a 21 - to $67-\mathrm{kb}$ mobile genetic element $[35,36]$. These elements have been classified into five major types and subtypes. Types IV and V are present on smaller DNA fragments and are easily transferable to other staphylococcal isolates compared to types I, II, and III, which are present on larger DNA fragments. A 
majority of HA-MRSA isolates are reported to carry longer transposable genetic elements, such as SCCmec type I, II, and III, and multidrug resistance genes, whereas CA-MRSA isolates are believed to carry a smaller number of genes, such as SCCmec type IV and $\mathrm{V}$, and are not multidrug-resistant [37]. In our study, we noticed that five of the six CAMRSA isolates were resistant to multiple drugs, such as chloramphenicol, erythromycin, tetracycline, trimethoprim, oxacillin, and methicillin, and carried SCCmec III. On the other hand, HA-MRSA isolates, apart from being resistant to the above antibiotics, also carried SCCmec III alone or in combination with SCCmec IVa and SCCmec V. The combined $\mathrm{SCC}$ mec III + IVa or SCCmec III + V types indicate a recombination between CA- and HAMRSA strains. Few reports of combined SCCmec types are available [31,38] and indicate a recombination between CA- and HA-MRSA isolates. A study of CA- and HA-MRSA isolates from Pakistan indicated that a majority of the HA-MRSA isolates were either SCCmec type III or its variants, and a majority of the CA-MRSA were SCCmec type IV or its variants [38,39]. A recently published study [40] from this region indicated that $47 \%$ of the clinical MRSA strains carried SCCmec type III and were PVL positive, while $29 \%$ exhibited SCCmec type IV and were PVL negative. In our study, the type distribution was as follows: SCCmec type III (53\%), type IVa (16\%), type V (5\%), types [III + IVa] (10\%), types $[\mathrm{III}+\mathrm{V}](10.5 \%)$, and types [III + IVa + V] $(10.5 \%)$. Data from our study and one published earlier [39] clearly indicate that the SCCmec type III is predominant in this geographical region; the second most prevalent is SCCmec type IV. Moreover, the earlier study indicated that only PVL-positive isolates showed SCCmec type IV elements, and those with the SCCmec type III elements were PVL negative. However, a closer look at the data from that study indicated that an almost equal number of strains with SCCmec type III also exhibited the presence of PVL genes. In our study, we did not see any correlation between CA-MRSA, SCCmec type, and the presence of PVL genes, as was emphasized in the earlier study [39]; PVL genes were present in all isolates included in our study. The presence of PVL genes in combination with the $t$ st gene that produces toxic shock syndrome toxin-1 (TSST-1) and causes toxic shock syndrome is reportedly a rare occurrence [41], but all of the isolates examined in this study contained both the PVL genes and the tst gene, which may indicate hypervirulence.

HA-MRSA isolates are known to cause serious and life-threatening diseases, while CA-MRSA isolates are believed to cause soft-tissue infections [42]. These concepts are now changing with the evolving nature of CA-MRSA as it is becoming a serious threat to public health due to its potential to cause necrotic lesions in skin or mucosa and necrotic hemorrhagic pneumonia, often with fatal outcomes [42]. Of the 19 isolates used in this study, six patients acquired MRSA in a community setting, and 13 acquired MRSA in a hospital setting. Two of the four CA-MRSA and four of the 13 HA-MRSA patients died while undergoing prolonged treatment. One CA-MRSA patient died due to septic shock, and one other CA-MRSA patient died due to chronic renal failure. Among four HA-MRSA patients that died, one died due to complications from renal failure, one from respiratory failure due to kyphoscoliosis, one from tetanus/lockjaw, and one from Guillain-Barre syndrome (GBS). Among the $S$. aureus isolates from the six patients that died, one exhibited the SCCmec type III (CA-MRSA isolate 33), two showed IVa (CA-MRSA isolate 25 and HA-MRSA isolate 40), one presented SCCmec [III + IVa] (HA-MRSA isolate 31), and two indicated SCCmec [III + V] (HA-MRSA isolates 10 and 51). Interestingly, MRSA isolates carrying SCCmec IVa or a combination of SCCmec [III + IVa] and SCCmec [III + V] were apparently associated with a higher number of deaths than those that carried SCCmec III. MRSA isolates from nine of the 13 patients who survived infection showed SCCmec III, one presented IVa, one showed V, and two contained a combination of SCCmec [III + IVa +V]. It appears that the combination of SCCmec III with either IVa or V contributes to the highest level of virulence. However, the patient infected with MRSA isolate 50, and carrying SCCmec [III + IVa + V] elements, did not exhibit life-threatening conditions. Recovery of this patient suggested that other factors, such as timely intervention, treatment options, 
and patient's condition when originally admitted, could play a crucial and effective role in combating these life-threatening infections.

The first step in the process of bacterial infection is the adherence of bacteria to human epithelial cells; this property has been used to define the pathogenicity of an infecting agent. Fibronectin binding proteins and their corresponding $f n b A$ and $f n b B$ genes have been proposed to be some of the major ligands on the staphylococcal cell surface that help S. aureus adhere to epithelial cells [43]. Approximately $90 \%$ of clinical isolates have been shown to contain the $f n b A$ gene, and only $20 \%$ have been shown to harbor the $f n b B$ gene [43]. The presence of both genes in S. aureus provides strong adherence properties and heightens pathogenicity. In our study, we observed that all MRSA isolates contained both $f n b A$ and $f n b B$ genes. In addition, eight of the 12 adhesion genes were commonly present in all isolates which potentially allows the bacteria to stick to a variety of surfaces and form a biofilm that renders them impermeable and resistant to various antimicrobial agents. One of the adhesion genes, namely ebpS, was predominantly present in $(6 / 8)$ isolates of perirectal origin rather than in nasal (2/11) isolates; implications of this difference are not currently known.

While the presence of adhesion genes offers $S$. aureus isolates the ability to adhere to different surfaces, the presence of hemolysin and toxin genes allow them to be highly pathogenic. Most isolates from human, bovine, and food sources have been reported to primarily possess the $\alpha$ hemolysin gene hla [44], which causes incomplete or partial hemolysis, but in our study, we noticed the presence of $\alpha, \beta$, and $\gamma$ hemolysin genes in both CA- and HA-MRSA isolates. These isolates were also found to contain several superantigen genes (sea, seb, sec, sed, see, seg, seh, sei, sej, tst) that have been reported to be responsible for the production of pro-inflammatory cytokines, infective endocarditis, scarlet fever, and possibly septic shock syndrome [45-47]. Several of these genes have been identified and reported in over $70 \%$ of $S$. aureus isolates [48]. Among the staphylococcal strains, tst is the most common superantigen gene associated with staphylococcal toxic shock syndrome; a high prevalence of sea $[45,46]$ and the superantigen genes seg and sei [47] have also been shown in patients with $S$. aureus-mediated septic shock and scarlet fever. The presence of these genes among S. aureus isolates evaluated in this study indicates a possibility that these isolates also have the potential to cause toxic shock syndrome. However, most patients admitted to intensive care units exhibited a variety of symptoms, and only one patient infected with CA-MRSA isolate 33 presented with this syndrome. This finding implies that other factors, such as differences in gene expression levels, biological activity, interactions with other cellular components, and genetic differences among individuals, may also play an important role in the outcome of $S$. aureus diseases and their manifestation, rather than the mere presence of such genes in associated isolates. The "agr locus", an accessory gene regulator, is a two-component quorum-sensing signaling pathway that controls the expression of many virulence factors in $S$. aureus. It encodes an autoinducing peptide (AIP), which exhibits the amino acid polymorphism in its sequence, and based on the polymorphism of the AIPs and their corresponding receptors, four major agr groups (I to IV) have been assigned [49]. The AIPs belonging to different groups are usually mutually inhibitory, but those within a group can activate the agr response in other member strains. All isolates used in this study belonged to the agr group I.

In summary, the present study identified eight ST types, three novel spa types, a combination of unique SCCmec types, specific virulence and pathogenicity markers, and their distribution and prevalence in CA- and HA-MRSA isolates from Pakistan. The most common spa type was t030, and the most prevalent ST type was ST239. All the isolates belonged to the agr group 1. Most of the isolates possessed SCCmec type III, and it was found to be predominantly present in these isolates either as a single SCCmec type or in combination with SCCmec IV and V. The presence of identical PFGE, MLST, and SCCmec patterns, as well as virulence and toxin genes in CA- and HA-MRSA isolates, suggests a transmission of these isolates and their traits between CA- and HA-MRSA and an evolutionary trend of $S$. aureus isolates in this geographical region. Our findings 
also suggest an erosion of a fine line of difference between CA-and HA-MRSA isolates, establishment of CA-MRSA isolates in hospital settings, and their evolution into powerful pathogens, all posing a serious challenge to public health both in hospital and in community settings. Poor hygienic conditions and the flow of people between hospital and community settings has provided ample opportunity for these pathogens to recombine and pass on traits to other organisms. These study findings clearly warrant a need for continued monitoring, epidemiological screening, and implementation of extreme measures to contain and control the spread of such pathogens.

\section{Materials and Methods}

\subsection{Isolation, Identification, and Characterization of Isolates}

Several presumptively positive Staphylococcus spp. isolates of the nasal and perirectal origin were obtained from multiple patients admitted to the intensive care unit (ICU) of a tertiary health care facility in Rawalpindi, Pakistan. Each of the strains used in the study was isolated from individual patients. Nineteen of these isolates were identified as methicillin-resistant Staphylococcus aureus based on their biochemical characterization with the Vitek identification method, nucA expression, and coagulase profile. HA-MRSA isolates represented the isolates from patients that were undergoing treatment in the hospital for something else but acquired MRSA infection during hospital stay. CA-MRSA isolates were obtained from the individuals that came to the hospital with MRSA infection and were admitted. Since methicillin-resistant strains cause severe and sometimes fatal infections, we used these strains for detailed molecular characterization.

\subsection{Antibiogram and MIC Using a Broth Dilution Method}

All isolates were tested for antimicrobial susceptibility against the criteria of the Clinical and Laboratory Standards Institute (CLSI) [50,51]. The following antibiotics, with their concentrations noted after their names in $\mu \mathrm{g} \mathrm{mL} \mathrm{m}^{-1}$, were tested to determine the susceptibility of $S$. aureus isolates: ampicillin-10, chloramphenicol-30, erythromycin-15, gentamicin-120, kanamycin-30, levofloxacin-2, oxacillin-1, methicillin-5, norfloxacin-5, penicillin-10, tetracycline-30, and vancomycin-30 (AB BIODISK, Piscataway, NJ, USA). Mueller-Hinton (MH) and Brain Heart Infusion agar plates (Thomas Scientific, Swedesboro, NJ, USA) were used as growth media for this purpose. The MIC was determined using a microdilution procedure described in an earlier study [52], where these methods have been described and results presented/discussed.

\subsection{DNA Plug Preparation and PFGE}

DNA plug preparation for PFGE analysis was carried out according to a Laboratory Protocol for molecular typing of $S$. aureus [53]. DNA plugs containing $S$. aureus genomic DNA were then digested with 30 units/plug of restriction enzyme SmaI (Promega, Madison, WI, USA) in a $200 \mu \mathrm{L}$ volume per manufacturer's recommendations. Digested DNA samples were separated in $1 \%$ SeaKem ${ }^{\circledR}$ Gold agarose gels (Cambrex Bio Science Rockland Inc., Rockland, ME, USA). The electrophoresis was carried out for $18.5-19 \mathrm{~h}$ in $0.5 \times \mathrm{TBE}$ (tris-borate- EDTA) using a CHEF Mapper (Bio-Rad, Hercules, CA, USA) at $200 \mathrm{~V}$ and $14{ }^{\circ} \mathrm{C}$, with initial and final switch times of 5 and 40 s. BioNumerics software v5.10 (Applied Maths Scientific Software Development, Saint-Martens-Latem, Belgium) was used for cluster analysis. Isolates with a similarity index of $\geq 88 \%$ were considered clones. PFGE strain types were compared to the USA100 MRSA isolate [12].

\subsection{DNA Isolation and Purification}

Chromosomal DNA for use in PCR was isolated from $S$. aureus strains grown overnight in a $\mathrm{MH}$ broth at $35^{\circ} \mathrm{C}$. Bacterial cell cultures $(1 \mathrm{~mL})$ were pelleted by centrifugation at $10,000 \times g$, and the pellet was suspended in $180 \mu \mathrm{L}$ TE buffer $(10 \mathrm{mM}$ Tris- $\mathrm{HCl}+1 \mathrm{mM}$ EDTA, pH 8.0) containing 10 units of lysostaphin (Sigma, St. Louis, MO, USA). Cell suspension was then incubated at $37^{\circ} \mathrm{C}$ for $1 \mathrm{~h}$. This was followed by proteinase $\mathrm{K}$ 
addition and incubation at $55{ }^{\circ} \mathrm{C}$ for $1 \mathrm{~h}$. An alkaline lysis (AL) solution $(200 \mu \mathrm{L})$, made by mixing AL1 and AL2 reagents from a QIAmp kit (Qiagen, Valencia, CA, USA), was added to the tube. Instructions included with the QIAmp kit were followed for S. aureus DNA purification. A nanodrop 2000 spectrophotometer (Thermo Fisher Scientific, Wilmington, DE, USA) was used to determine DNA concentrations by reading absorbance at 260 and $280 \mathrm{~nm}$.

\subsection{Hemolysin Assay}

Hemolysin activity was measured using a simple sheep blood agar plate-based assay. Plates containing $7 \%$ sheep blood were washed twice with $0.85 \%$ sterile $\mathrm{NaCl}$ solution. Bacterial strains were then spot inoculated, and plates were incubated at $37^{\circ} \mathrm{C}$ for $16-18 \mathrm{~h}$. Plates were then incubated at $4{ }^{\circ} \mathrm{C}$ overnight to distinguish hemolysis zones of clearance pertaining to $\alpha, \beta$, and $\delta$ hemolysins. Sharp clear edges of the lysis zones indicated the presence of $\beta$ hemolysin. Presence of $\alpha$ and $\delta$ hemolysins was indicated by the observation of discolored zones of clearance without sharp edges as a result of incomplete lysis of hemoglobin [54]. The presence of hemolysin genes $\alpha, \beta$, and $\gamma$ was also determined by PCR amplification as described earlier [55].

\subsection{Antimicrobial Resistance Genes}

The methicillin resistance determinant gene mec $A$ and the heat-stable nuclease gene $n u c A$ were amplified from $S$. aureus isolates as $533 \mathrm{bp}$ and $270 \mathrm{bp}$ DNA fragments, respectively, using primers and amplification protocols described previously [56]. Antimicrobial resistance genes encoding aminoglycoside resistance $\left(a a c\left(6^{\prime}\right)\right.$-aph $\left(2^{\prime \prime}\right)$, ant $\left(4^{\prime}\right)-I a, a p h\left(3^{\prime}\right)-I I I a$, $a a c\left(6^{\prime}\right)-I e-a p h\left(2^{\prime}\right)-I a, s t r$, and sat4) and genes conferring resistance to beta-lactams ( $m e c A$ and blaZ), macrolides ( $m p h C, e r m C$, and ermB), tetracycline (tet $K$ and tet $M)$, and chloramphenicol (catpC221 and catpC223) were amplified by using PCR primers and conditions described in previous publications [57-61].

\subsection{Toxin and Virulence Genes}

S. aureus chromosomal DNA was used for PCR assays to amplify 19 toxin genes (sea, seb, sec, sed, see, seg, seh, sei, sej, tst, edin, eta, etb, hla, hlb, hld, hlg, hlg2, and PVL), 12 adhesin genes (bbp, clfA, clfB, cna, ebpS, fnbA, fnbB, map/eap, sdrC, sdrD, sdrE, and spa), and five other virulence genes (chp, efb, ica $A, V 8$, and $\operatorname{arc} A)$, using primers and conditions described earlier $[62,63]$. Moreover, all $S$. aureus isolates were also screened for the presence of $\operatorname{arc} A$ and agr groups I to IV genes using PCR primers and conditions described earlier [40]. PCR reactions were performed in a MyCycler thermal cycler (Bio-Rad, Hercules, CA, USA) with HotStart Taq polymerase (Qiagen), and PCR products were analyzed by electrophoresis in a $2 \%$ agarose gel.

\subsection{PVL Gene Amplification, MLST and spa Typing}

MLST is another discriminatory tool used to characterize bacterial isolates based on the sequencing of $~ 450$-bp internal fragments of seven housekeeping genes [64]. These included acetyl coenzyme A acetyltransferase (yqiL), carbamate kinase (arcC), glycerol kinase $(g l p)$, guanylate kinase $(g m k)$, phosphate acetyltransferase $(p t a)$, shikimate dehydrogenase $(a r o E)$, and triosephosphate isomerase (tpi). Primers and amplification procedures for these genes were used as described earlier [65], followed by sequencing of PCR fragments using an ABI prism BigDye Terminator cycle sequencing ready reaction kit (Applied Biosystems, Foster City, CA, USA) and MLSTs mapping via the https:/ / pubmlst.org/organisms/staphylococcus-aureus/ (accessed on 20 April 2021). For each housekeeping gene, the distinct sequences were given different allele numbers. The alleles at each of the seven loci among bacterial isolates represented a series of seven integers and defined its allelic profile. Each allelic profile was assigned a distinct multilocus sequence type or, in short, an ST number (e.g., ST22). 
For typing the spa region (a $3^{\prime}$ coding region $\mathrm{X}$ of the $S$. aureus-specific staphylococcal protein A gene), a polymorphic 24-bp variable-number tandem repeat (VNTR) within this gene was used to discriminate between the outbreak strains of MRSA [66]. The source of variation in this region is due to the duplication or deletion of the 24-bp repetitive units. Therefore, sequencing of the $\mathrm{X}$ region of the spa gene was carried out with a slight modification of the method described earlier [67] and with an alternate forward primer [68]. Sequencing of the PCR products was done using an ABI prism BigDye Terminator cycle sequencing ready reaction kit (Applied Biosystems, Waltham, MA, USA). Spa-types were determined using the website http:/ / spatyper.fortinbras.us / (accessed on 20 April 2021), following the sequencing of the variable $X$ region of the spa gene.

Primers for the $l u k S$ and $l u k F$ genes were designed with the primer select module of the Lasergene program (DNASTAR, Inc., Madison, WI, USA) using previously published sequences for these genes (AB186917). Primers were synthesized by Eurofins MWG Operon (Huntsville, AL, USA). Primers for the $l u k S$ genes were $l u k S$-FW 5'-AACAGAAGATACAAGATACAAGTAGCGATAA- $3^{\prime}$ and $l u k S-R$ 5 $5^{\prime}$-GTCTGGCACAAAATAGTCTCT- $3^{\prime}$. The primers for $l u k F$ gene amplification were $l u k F-F W 5^{\prime}$-ACGGTAGGTTATTCTTATG-3 ${ }^{\prime}$ and lukF-R 5'-AATTATTACCTATCCAGTGA-3'. Amplification of other leucotoxin genes such as $l u k E-D(l u k E+l u k D)$ and $l u k M$ was also carried out using primers and PCR conditions described in a previous publication [69]. Each reaction tube contained $0.1-0.5 \mu \mathrm{g}$ of bacterial DNA $(5 \mu \mathrm{L})$, a $10 \mu \mathrm{M}$ mixture of the forward and reverse primers $(5 \mu \mathrm{L})$, and $15 \mu \mathrm{L} \mathrm{PCR}$ mix $(200 \mu \mathrm{L}$ PCR mix contained $100 \mu \mathrm{L}$ 2X DreamTaq PCR Master Mix (ThermoFisher Scientific, Carlsbad, CA, USA), $27 \mu \mathrm{L}$ of $25 \mathrm{mM}$ magnesium acetate, $66 \mu \mathrm{L}$ of $10 \mathrm{mM} \mathrm{dNTP}$ mix, and $7 \mu \mathrm{L}$ Taq DNA polymerase). An initial denaturation step was carried out at $95^{\circ} \mathrm{C}$ for $3 \mathrm{~min}$, followed by 35 cycles consisting of $94^{\circ} \mathrm{C}$ denaturation for $60 \mathrm{~s}, 50{ }^{\circ} \mathrm{C}$ annealing for $50 \mathrm{~s}$, and $72{ }^{\circ} \mathrm{C}$ extension for $50 \mathrm{~s}$. The extension step in the last cycle was prolonged for 5 min. PCR amplicons were analyzed on $1.5 \%$ agarose gels.

\subsection{SCCmec and agr Group Typing}

SCCmec types I to V and subtypes IVa, b, c, and d, as described earlier [35,69], were detected with a simple PCR method developed previously [36]. All PCR primers and conditions to amplify these genes were used as described in the publication [36]. Classification of various MRSA isolates into agr groups I to IV, as described by Azimian et al. [49], was also performed by PCR using primers and amplification conditions described by Peacock et al. [70].

\subsubsection{Determination of the Capsular Polysaccharide Type}

A reliable PCR method for the detection of capsular type 5 (361 bp) and for capsular type $8(173 \mathrm{bp})$ was used to determine the serotype of all MRSA strains used in the study, by using primers and conditions described earlier [71].

\subsubsection{Sequence Analysis}

PCR products were purified with a QIAquick gel extraction kit (Qiagen, Germantown, MD, USA), eluted in nuclease-free water, and sequenced by the BigDye sequencing method described above. Nucleotide sequences of the PCR products were BLAST searched against the existing GenBank database to confirm their identity.

Supplementary Materials: The following are available online at https:/ / www.mdpi.com/article/10 .3390/pathogens10080918/s1, Table S1: Antibiogram and MIC data for MRSA isolates from Pakistan.

Author Contributions: S.K. had the original idea for the manuscript and carried out the MLST analysis, PVL, spa, agr, and capsular typing. B.S.M. carried out PCR analysis of the toxin, adhesin, and virulence genes. M.N. performed antimicrobial susceptibility and hemolysin assays. K.S. performed the PFGE analysis, SCCmec typing, and sequence analysis. B.S.M. helped in preparing the manuscript after discussion and input from all the authors. S.K. critically revised the manuscript and 
verified detection methods and results. All authors have read and agreed to the published version of the manuscript.

Funding: The project was supported by internal funding from NCTR.

Institutional Review Board Statement: Not applicable.

Informed Consent Statement: Not applicable.

Data Availability Statement: Not applicable.

Acknowledgments: The authors thank Huizhong Chen and Steven Foley of the Division of Microbiology, NCTR, for critical reading and evaluation of the manuscript. Bacterial strains used in the study were provided by Saira Iram of the Quaid-I-Azam University, Pakistan and are maintained in our culture collection, although this is not an ongoing, active collaboration. We also acknowledge the use of the S. aureus MLST database developed by Jolley et al Wellcome Open Research 2018, 3:124, and funded by the Welcome Trust. The work was supported by the US Food and Drug Administration. Views presented in this paper do not necessarily reflect those of the FDA.

Conflicts of Interest: The authors declare no conflict of interest.

\section{References}

1. Fey, P.D.; Said-Salim, B.; Rupp, M.E.; Hinrichs, S.H.; Boxrud, D.J.; Davis, C.C.; Kreiswirth, B.N.; Schlieveret, P.M. Comparative molecular analysis of community- or hospital-acquired methicillin-resistant Staphylococcus aureus. Antimicrob. Agents Chemother. 2003, 47, 196-203. [CrossRef]

2. Fukuta, Y.; Cunningham, C.A.; Harris, P.L.; Wagener, M.M.; Muder, R.R. Identifying the risk factors for hospital-acquired methicillin-resistant Staphylococcus aureus (MRSA) infection among patients colonized with MRSA on admission. Infect. Control Hosp. Epidemiol. 2012, 33, 1219-1225. [CrossRef]

3. Boucher, H.W.; Corey, G.R. Epidemiology of methicillin-resistant Staphylococcus aureus. Clin. Infect. Dis. 2008, 46 (Suppl. S5), S344-S449. [CrossRef]

4. Eriksen, K.R. “Celbenin”-resistant staphylococci. Ugeskr. Laeger. 1961, 123, 384-386. [PubMed]

5. Ahmad, M.K.; Asrar, A. Prevalence of methicillin resistant Staphylococcus aureus in pyogenic community and hospital acquired skin and soft tissues infections. J. Pak. Med. Assoc. 2014, 64, 892-895.

6. Taj, Y.; Abdullah, F.E.; Kazmi, S.U. Current pattern of antibiotic resistance in Staphylococcus aureus clinical isolates and the emergence of vancomycin resistance. J. Coll. Physicians Surg. Pak. 2010, 20, 728-732.

7. Hussain, M.S.; Naqvi, A.; Sharaz, M. Methicillin resistant Staphylococcus aureus (MRSA); prevalence and susceptibility pattern of (MRSA) isolated from pus in tertiary care of district hospital of Rahim Yar Khan. Prof. Med. J. 2019, 26, 122-127. [CrossRef]

8. Watkins, R.R.; David, M.Z.; Salata, R.A. Current concepts on the virulence mechanisms of meticillin-resistant Staphylococcus aureus. J. Med. Microbiol. 2012, 61, 1179-1193. [CrossRef]

9. Ladhani, S.; Garbash, M. Staphylococcal skin infections in children: Rational drug therapy recommendations. Paediatr. Drugs 2005, 7, 77-102. [CrossRef]

10. Bernard, P. Management of common bacterial infections of the skin. Curr. Opin. Infect. Dis. 2008, 21, 122-128. [CrossRef]

11. Liu, C.; Bayer, A.; Cosgrove, S.E.; Daum, R.S.; Fridkin, S.K.; Gorwitz, R.J.; Kaplan, S.L.; Karchmer, A.W.; Levine, D.P.; Murray, B.E.; et al. Clinical practice guidelines by the infectious diseases society of america for the treatment of methicillin-resistant Staphylococcus aureus infections in adults and children: Executive summary. Clin. Infect. Dis. 2011, 52, 285-292. [CrossRef] [PubMed]

12. Chambers, H.F.; Deleo, F.R. Waves of resistance: Staphylococcus aureus in the antibiotic era. Nat. Rev. Microbiol. 2009, 7, 629-641. [CrossRef] [PubMed]

13. Deresinski, S. Methicillin-resistant Staphylococcus aureus: An evolutionary, epidemiologic, and therapeutic odyssey. Clin. Infect. Dis. 2005, 40, 562-573. [CrossRef] [PubMed]

14. Patel, M.; Waites, K.B.; Moser, S.A.; Cloud, G.A.; Hoesley, C.J. Prevalence of inducible clindamycin resistance among communityand hospital-associated Staphylococcus aureus isolates. J. Clin. Microbiol. 2006, 44, 2481-2484. [CrossRef] [PubMed]

15. Gupta, A.K.; Lyons, D.C.; Rosen, T. New and emerging concepts in managing and preventing community-associated methicillinresistant Staphylococcus aureus infections. Int. J. Dermatol. 2015, 54, 1226-1232. [CrossRef]

16. Boyle-Vavra, S.; Daum, R.S. Community-acquired methicillin-resistant Staphylococcus aureus: The role of Panton-Valentine leukocidin. Lab. Investig. 2007, 87, 3-9. [CrossRef]

17. Nair, G.B.; Niederman, M.S. Community-acquired pneumonia: An unfinished battle. Med. Clin. N. Am. 2011, 95, 1143-1161. [CrossRef]

18. Graves, S.F.; Kobayashi, S.D.; DeLeo, F.R. Community-associated methicillin-resistant Staphylococcus aureus immune evasion and virulence. J. Mol. Med. 2010, 88, 109-114. [CrossRef] 
19. Tristan, A.; Bes, M.; Meugnier, H.; Lina, G.; Bozdogan, B.; Courvalin, P.; Reverdy, M.E.; Enright, M.C.; Vandenesch, F.; Etienne, J. Global distribution of Panton-Valentine leukocidin-positive methicillin-resistant Staphylococcus aureus. Emerg. Infect. Dis. 2007, 13, 594-600. [CrossRef] [PubMed]

20. Kaneko, J.; Kamio, Y. Bacterial two-component and hetero-heptameric pore-forming cytolytic toxins: Structures, pore-forming mechanism, and organization of the genes. Biosci. Biotechnol. Biochem. 2004, 68, 981-1003. [CrossRef] [PubMed]

21. Holden, M.T.; Feil, E.J.; Lindsay, J.A.; Peacock, S.J.; Day, N.P.; Enright, M.C.; Foster, T.J.; Moore, C.E.; Hurst, L.; Atkin, R.; et al. Complete genomes of two clinical Staphylococcus aureus strains: Evidence for the rapid evolution of virulence and drug resistance. Proc. Natl. Acad. Sci. USA 2004, 101, 9786-9791. [CrossRef]

22. Hookey, J.V.; Richardson, J.F.; Cookson, B.D. Molecular typing of Staphylococcus aureus based on PCR restriction fragment length polymorphism and DNA sequence analysis of the coagulase gene. J. Clin. Microbiol. 1998, 36, 1083-1089. [CrossRef]

23. Booth, M.C.; Hatter, K.L.; Miller, D.; Davis, J.; Kowalski, R.; Parke, D.W.; Chodosh, J.; Jett, B.D.; Callegan, M.C.; Penland, R.; et al. Molecular epidemiology of Staphylococcus aureus and Enterococcus faecalis in endophthalmitis. Infect. Immun. 1998, 66, 356-360. [CrossRef] [PubMed]

24. Nowrouzian, F.L.; Karami, N.; Welinder-Olsson, C.; Ahren, C. Virulence gene typing of methicillin-resistant Staphylococcus aureus as a complement in epidemiological typing. J. Microbiol. Methods 2013, 93, 173-176. [CrossRef]

25. Naimi, T.S.; LeDell, K.H.; Como-Sabetti, K.; Borchardt, S.M.; Boxrud, D.J.; Etienne, J.; Johnson, S.K.; Vandenesch, F.; Fridkin, S.; O'Boyle, C.; et al. Comparison of community- and health care-associated methicillin-resistant Staphylococcus aureus infection. JAMA 2003, 290, 2976-2984. [CrossRef]

26. Calfee, D.P. The epidemiology, treatment, and prevention of transmission of methicillin-resistant Staphylococcus aureus. J. Infus. Nurs. 2011, 34, 359-364. [CrossRef]

27. Jimenez, J.N.; Ocampo, A.M.; Vanegas, J.M.; Rodriguez, E.A.; Mediavilla, J.R.; Chen, L.; Muskus, C.E.; Vélez, L.A.; Rojas, C.; Restrepo, A.V.; et al. CC8 MRSA strains harboring SCCmec type IVc are predominant in Colombian hospitals. PLoS ONE 2012, 7, e38576.

28. Teixeira, M.M.; Araujo, M.C.; Silva-Carvalho, M.C.; Beltrame, C.O.; Oliveira, C.C.H.B.; Figueiredo, A.M.S.; Oliveira, A.G. Emergence of clonal complex 5 (CC5) methicillin-resistant Staphylococcus aureus (MRSA) isolates susceptible to trimethoprimsulfamethoxazole in a Brazilian hospital. Braz. J. Med. Biol. Res. 2012, 45, 637-643. [CrossRef]

29. Deurenberg, R.H.; Stobberingh, E.E. The molecular evolution of hospital- and community-associated methicillin-resistant Staphylococcus aureus. Curr. Mol. Med. 2009, 9, 100-115. [CrossRef]

30. Madzgalla, S.; Syed, M.A.; Khan, M.A.; Rehman, S.S.; Muller, E.; Reissig, A.; Ehricht, R.S.; Monecke, S. Molecular characterization of Staphylococcus aureus isolates causing skin and soft tissue infections in patients from Malakand, Pakistan. Eur. J. Clin. Microbiol. Infect. Dis. 2016, 35, 1541-1547. [CrossRef]

31. Zafar, A.; Stone, M.; Ibrahim, S.; Parveen, Z.; Hasan, Z.; Khan, E.; Hasan, R.; Wain, J.; Bamford, K. Prevalent genotypes of meticillin-resistant Staphylococcus aureus: Report from Pakistan. J. Med. Microbiol. 2011, 60, 56-62. [CrossRef]

32. Shabir, S.; Hardy, K.J.; Abbasi, W.S.; McMurray, C.L.; Malik, S.A.; Wattal, C.; Hawkey, P.M. Epidemiological typing of meticillinresistant Staphylococcus aureus isolates from Pakistan and India. J. Med. Microbiol. 2010, 59, 330-337. [CrossRef] [PubMed]

33. Yamamoto, T.; Takano, T.; Higuchi, W.; Iwao, Y.; Singur, O.; Reva, I.; Otsuka, Y.; Nakayashiki, T.; Mori, H.; Reva, G.; et al. Comparative genomics and drug resistance of a geographic variant of ST239 methicillin-resistant Staphylococcus aureus emerged in Russia. PLoS ONE 2012, 7, e29187. [CrossRef]

34. Shore, A.; Rossney, A.S.; Keane, C.T.; Enright, M.C.; Coleman, D.C. Seven novel variants of the staphylococcal chromosomal cassette mec in methicillin-resistant Staphylococcus aureus isolates from Ireland. Antimicrob. Agents Chemother. 2005, 49, 2070-2083. [CrossRef] [PubMed]

35. International Working Group on the Classification of Staphylococcal Cassette Chromosome E. Classification of staphylococcal cassette chromosome mec (SCCmec): Guidelines for reporting novel SCCmec elements. Antimicrob. Agents Chemother. 2009, 53, 4961-4967. [CrossRef]

36. Chongtrakool, P.; Ito, T.; Ma, X.X.; Kondo, Y.; Trakulsomboon, S.; Tiensasitorn, C.; Jamklang, M.; Chavalit, T.; Song, J.H.; Hiramatsu, K. Staphylococcal cassette chromosome mec (SCCmec) typing of methicillin-resistant Staphylococcus aureus strains isolated in 11 Asian countries: A proposal for a new nomenclature for SCCmec elements. Antimicrob. Agents Chemother. 2006, 50, 1001-1012. [CrossRef]

37. Palavecino, E. Community-acquired methicillin-resistant Staphylococcus aureus infections. Clin. Lab. Med. 2004, 24, 403-418. [CrossRef]

38. Monecke, S.; Coombs, G.; Shore, A.C.; Coleman, D.C.; Akpaka, P.; Borg, M.; Chow, H.; Ip, M.; Jatzwauk, L.; Jonas, D.; et al. A field guide to pandemic, epidemic and sporadic clones of methicillin-resistant Staphylococcus aureus. PLoS ONE 2011, 6, e17936. [CrossRef]

39. Asghar, A.H. Molecular characterization of methicillin-resistant Staphylococcus aureus isolated from tertiary care hospitals. Pak. J. Med. Sci. 2014, 30, 698-702. [CrossRef]

40. Campbell, S.J.; Deshmukh, H.S.; Nelson, C.L.; Bae, I.G.; Stryjewski, M.E.; Federspiel, J.J.; Tonthat, G.T.; Rude, T.H.; Barriere, S.L.; Corey, R.; et al. Genotypic characteristics of Staphylococcus aureus isolates from a multinational trial of complicated skin and skin structure infections. J. Clin. Microbiol. 2008, 46, 678-684. [CrossRef] 
41. Li, Z.; Stevens, D.L.; Hamilton, S.M.; Parimon, T.; Ma, Y.; Kearns, A.M.; Ellis, R.W.; Bryant, A.E. Fatal S. aureus hemorrhagic pneumonia: Genetic analysis of a unique clinical isolate producing both PVL and TSST-1. PLoS ONE 2011, 6, e27246. [CrossRef]

42. Lina, G.; Piemont, Y.; Godail-Gamot, F.; Bes, M.; Peter, M.O.; Gauduchon, V.; Vandenesch, F.; Etienne, J. Involvement of PantonValentine leukocidin-producing Staphylococcus aureus in primary skin infections and pneumonia. Clin. Infect. Dis. 1999, 29, 1128-1132. [CrossRef] [PubMed]

43. Mongodin, E.; Bajolet, O.; Cutrona, J.; Bonnet, N.; Dupuit, F.; Puchelle, E.; Bentzmann, S. Fibronectin-binding proteins of Staphylococcus aureus are involved in adherence to human airway epithelium. Infect. Immun. 2002, 70, 620-630. [CrossRef] [PubMed]

44. Salasia, S.I.; Tato, S.; Sugiyono, N.; Ariyanti, D.; Prabawati, F. Genotypic characterization of Staphylococcus aureus isolated from bovines, humans, and food in Indonesia. J. Vet. Sci. 2011, 12, 353-361. [CrossRef]

45. Dinges, M.M.; Orwin, P.M.; Schlievert, P.M. Exotoxins of Staphylococcus aureus. Clin. Microbiol. Rev. 2000, 13, 16-34. [CrossRef]

46. Ferry, T.; Thomas, D.; Genestier, A.L.; Bes, M.; Lina, G.; Vandenesch, F.; Etienne, J. Comparative prevalence of superantigen genes in Staphylococcus aureus isolates causing sepsis with and without septic shock. Clin. Infect. Dis. 2005, 41, 771-777. [CrossRef]

47. Jarraud, S.; Cozon, G.; Vandenesch, F.; Bes, M.; Etienne, J.; Lina, G. Involvement of enterotoxins G and I in staphylococcal toxic shock syndrome and staphylococcal scarlet fever. J. Clin. Microbiol. 1999, 37, 2446-2449. [CrossRef]

48. Becker, K.; Friedrich, A.W.; Lubritz, G.; Weilert, M.; Peters, G.; Von Eiff, C. Prevalence of genes encoding pyrogenic toxin superantigens and exfoliative toxins among strains of Staphylococcus aureus isolated from blood and nasal specimens. J. Clin. Microbiol. 2003, 41, 1434-1439. [CrossRef] [PubMed]

49. Azimian, A.; Najar-Pirayeh, S.; Mirab-Samiee, S.; Naderi, M. Occurrence of methicillin resistant Staphylococcus aureus (MRSA) among clinical samples in tehran-iran and its correlation with polymorphism of specific accessory gene regulator (AGR) groups. Braz. J. Microbiol. 2012, 43, 779-785. [CrossRef] [PubMed]

50. CLSI. Performance Standards for Antimicrobial Disk Susceptibility Tests; Clinical and Laboratory Standards Institute: Wayne, PA, USA, 2009.

51. CLSI. Methods for Dilution Antimicrobial Susceptibility Tests for Bacteria that Grow Aerobically; Clinical and Laboratory Standards Institute: Wayne, PA, USA, 2009.

52. Marasa, B.S.; Iram, S.; Sung, K.; Kweon, O.G.; Cerniglia, C.E.; Khan, S. Molecular characterization of fluoroquinolone resistance of methicillin-resistant clinical Staphylococcus aureus isolates from Rawalpindi, Pakistan. Med. Res. Arch. 2015, 2, 1-14.

53. McDougal, L.K.; Steward, C.D.; Killgore, G.E.; Chaitram, J.M.; McAllister, S.K.; Tenover, F.C. Pulsed-field gel electrophoresis typing of oxacillin-resistant Staphylococcus aureus isolates from the United States: Establishing a national database. J. Clin. Microbiol. 2003, 41, 5113-5120. [CrossRef]

54. Lattar, S.M.; Tuchscherr, L.P.; Caccuri, R.L.; Centron, D.; Becker, K.; Alonso, C.A.; Barberis, C.; Miranda, G.; Buzzola, F.R.; Eiff, C.V.; et al. Capsule expression and genotypic differences among Staphylococcus aureus isolates from patients with chronic or acute osteomyelitis. Infect. Immun. 2009, 77, 1968-1975. [CrossRef]

55. Haveri, M.; Roslof, A.; Rantala, L.; Pyorala, S. Virulence genes of bovine Staphylococcus aureus from persistent and nonpersistent intramammary infections with different clinical characteristics. J. Appl. Microbiol. 2007, 103, 993-1000. [CrossRef]

56. Fomda, B.A.; Thokar, M.A.; Bashir, G.; Khan, A.; Kour, A.; Zahoor, D.; Ray, P. Prevalence and genotypic relatedness of methicillin resistant Staphylococcus aureus in a tertiary care hospital. J. Postgrad. Med. 2014, 60, 386-389. [CrossRef] [PubMed]

57. Schmitz, F.J.; Fluit, A.C.; Gondolf, M.; Beyrau, R.; Lindenlauf, E.; Verhoef, J.; Ray, P. The prevalence of aminoglycoside resistance and corresponding resistance genes in clinical isolates of staphylococci from 19 European hospitals. J. Antimicrob. Chemother. 1999, 43, 253-259. [CrossRef] [PubMed]

58. Olsen, J.E.; Christensen, H.; Aarestrup, F.M. Diversity and evolution of blaZ from Staphylococcus aureus and coagulase-negative staphylococci. J. Antimicrob. Chemother. 2006, 57, 450-460. [CrossRef]

59. Schmitz, F.J.; Sadurski, R.; Kray, A.; Boos, M.; Geisel, R.; Kohrer, K.; Jan Verhoefband, J.; Fluit, A.C. Prevalence of macrolideresistance genes in Staphylococcus aureus and Enterococcus faecium isolates from 24 European university hospitals. J. Antimicrob. Chemother. 2000, 45, 891-894. [CrossRef] [PubMed]

60. Lim, K.T.; Hanifah, Y.A.; Yusof, M.; Thong, K.L. ermA, ermC, tetM and tetK are essential for erythromycin and tetracycline resistance among methicillin-resistant Staphylococcus aureus strains isolated from a tertiary hospital in Malaysia. Indian J. Med. Microbiol. 2012, 30, 203-207. [CrossRef]

61. Kadlec, K.; Fessler, A.T.; Hauschild, T.; Schwarz, S. Novel and uncommon antimicrobial resistance genes in livestock-associated methicillin-resistant Staphylococcus aureus. Clin. Microbiol. Infect. 2012, 18, 745-755. [CrossRef]

62. Li, J.; Wang, L.; Ip, M.; Sun, M.; Sun, J.; Huang, G.; Wang, C.; Deng, L.; Zheng, Y.; Fu, Z.; et al. Molecular and clinical characteristics of clonal complex 59 methicillin-resistant Staphylococcus aureus infections in Mainland China. PLoS ONE 2013, 8, e70602. [CrossRef]

63. Orii, K.O.; Iwao, Y.; Higuchi, W.; Takano, T.; Yamamoto, T. Molecular characterization of methicillin-resistant Staphylococcus aureus from a fatal case of necrotizing fasciitis in an extremely low-birth-weight infant. Clin. Microbiol. Infect. 2010, 16, $289-292$. [CrossRef]

64. Saunders, N.A.; Holmes, A. Multilocus sequence typing (MLST) of Staphylococcus aureus. Methods Mol. Biol. 2014, 1085, 113-130. 
65. Heym, B.; Le Moal, M.; Armand-Lefevre, L.; Nicolas-Chanoine, M.H. Multilocus sequence typing (MLST) shows that the 'Iberian' clone of methicillin-resistant Staphylococcus aureus has spread to France and acquired reduced susceptibility to teicoplanin. J. Antimicrob. Chemother. 2002, 50, 323-329. [CrossRef]

66. Koreen, L.; Ramaswamy, S.V.; Graviss, E.A.; Naidich, S.; Musser, J.M.; Kreiswirth, B.N. Spa typing method for discriminating among Staphylococcus aureus isolates: Implications for use of a single marker to detect genetic micro- and macrovariation. J. Clin. Microbiol. 2004, 42, 792-799. [CrossRef]

67. Hallin, M.; Friedrich, A.W.; Struelens, M.J. Spa typing for epidemiological surveillance of Staphylococcus aureus. Methods Mol. Biol. 2009, 551, 189-202.

68. Votintseva, A.A.; Fung, R.; Miller, R.R.; Knox, K.; Godwin, H.; Wyllie, D.H.; Bowden, R.; Crook, D.W.; Walke, A.S. Prevalence of Staphylococcus aureus protein A (spa) mutants in the community and hospitals in Oxfordshire. BMC Microbiol. 2014, 14, 63. [CrossRef]

69. Hata, E.; Katsuda, K.; Kobayashi, H.; Uchida, I.; Tanaka, K.; Eguchi, M. Genetic variation among Staphylococcus aureus strains from bovine milk and their relevance to methicillin-resistant isolates from humans. J. Clin. Microbiol. 2010, 48, 2130-2139. [CrossRef]

70. Peacock, S.J.; Moore, C.E.; Justice, A.; Kantzanou, M.; Story, L.; Mackie, K.; O’Neill, G.; Day, N.P.J. Virulent combinations of adhesin and toxin genes in natural populations of Staphylococcus aureus. Infect Immun. 2002, 70, 4987-4996. [CrossRef] [PubMed]

71. Verdier, I.; Durand, G.; Bes, M.; Taylor, K.L.; Lina, G.; Vandenesch, F.; Fattom, A.I.; Etienne, J. Identification of the capsular polysaccharides in Staphylococcus aureus clinical isolates by PCR and agglutination tests. J. Clin. Microbiol. 2007, 45, 725-729. [CrossRef] 